\title{
FROM OUTSETTING BARD TO MATURE POET: WHITMAN'S "OUT OF THE CRADLE” AND THE SEA-DRIFT CLUSTER
}

\author{
A. JAMES WOHLPART
}

EXCEPT FOR Robin FAST's ANALYSIS of the poet's vocation in the eleven poems comprising the Sea-Drift cluster of Whitman's 1881 Leaves of Grass, only one other reading, that by Robert LaRue focusing on sea imagery, has attempted any kind of synthetic analysis of these poems. ${ }^{1}$ As Fast notes, the predominant approach to Sea-Drift has been an analysis of the two major poems of the cluster, "Out of the Cradle Endlessly Rocking" and "As I Ebb'd with the Ocean of Life," and the way in which these poems develop one of Whitman's major themes: the immortal nature of the human soul. However, a closer look at the theme of immortality in the cluster as a whole, beginning with a detailed analysis of the opening poems "Out of the Cradle" and "As I Ebb'd" followed by a discussion of the other nine poems which make up the cluster, will demonstrate a marked progression in the development of this theme. Rather than, as many critics have claimed, the outsetting bard's complete understanding of the concept of immortality, and the way in which immortality will operate as a foundation for his poetry, at the end of "Out of the Cradle," the voice of the outsetting bard only reveals an incipient understanding of mortality. While the voice of the mature poet in "Out of the Cradle" clearly comprehends the depth of this concept, it is only through the process of the cluster as a whole that Whitman fully develops the theme of immortality.

The conflation of voices in "Out of the Cradle Endlessly Rocking," occurring primarily through Whitman's conflation of time in the poem, has led critics to assume that the boy-poet at the end of the unfolding drama is the same as the mature poet who speaks the opening stanza. For instance, Leo Spitzer concludes that once the boy hears the word spoken by the sea, the word "death," he discovers the "meaning of life, which is death, [and] he is no longer the boy of the beginning. . . . He has become the poet, the 'uniter of here and hereafter'...."2 Gay Wilson Allen similarly concludes, in A Reader's Guide to Walt Whitman, that "What the poem is really about is how the boy became a man and a poet through the childhood initiation into the mystery of death and maternity." "Even while analyzing the cluster as a whole, Robin Fast comes to a similar conclusion. Fast claims that, at the end of the poem, 
the outsetting bard "reconciles himself to death" because he realizes that "death cannot truly separate the dead from the living, and life is part of a larger reality which includes all." 4 The conclusion that most critics have reached is that "Out of the Cradle" shows not only the awakening of the poet but also his full maturity, his full knowledge of one of his major themes, at this very same moment of awakening.

More recently, however, critics have suggested that the boy-poet's knowledge at the end of the poem is not as complete as that which the mature poet attains some years later; indeed, it is only the knowledge that the mature poet attains which allows him to recreate the scene with some semblance of meaning. In his cursory analysis of the Sea-Drift cluster, which focuses on "Out of the Cradle," James Perrin Warren claims that "Out of the Cradle' does not complete the story of the poet's spiritual birth and growth."6 Rather, Whitman presents two distinct voices in the poem, that of the outsetting bard and that of the mature poet, each representing different levels of maturity and knowledge. An attempt to separate these voices in "Out of the Cradle" will help to show the way in which the boy-poet's defining of the word "death" is not as complete as has been suggested and thus that his maturity as a poet is not fully attained at the end of the poem.

In the opening, introductory stanza, ${ }^{7}$ the mature poet begins reflecting on his experience as a boy. He concludes: "I . . . / A reminiscence sing." 8 In this stanza, composed of a single sentence, the narrator speaks in a distinct voice, giving a strong sense of the mature poet's knowledge and the way in which it differs from the boy-poet's knowledge. The imagery of the first few lines suggests the mature poet's knowledge of immortality as he sings of the "endlessly rocking" cradle (1. 1), symbolic of constant birth and thus re-birth, and of the "Ninthmonth" (1.3), symbolic of both birth (the gestation period) and death (September and thus autumn). The poet emphasizes the merging of birth and death in "the sterile sands and the fields beyond" of the next line, again suggesting an association of death and life. These opening lines, which bring together not only death and life but death in life (the month of birth, perhaps of the endlessly rocking cradle, occurs in autumn), suggest the mature poet's awareness of immortality.

The next section of the introductory stanza introduces the subject matter of the reminiscence, the poet's experience as a boy with the bird and the sea. Significantly, the images that were joined in the opening lines to suggest immortality, such as the "sterile sands" and the living "fields," are now separated as the mature poet reflects on himself as a boy. He begins "Out from the patches of briers and blackberries" (1.7) and concludes twelve lines later with "Throwing myself on the sand" (1.19). The initial description of his boyhood experiences hints at the many images that will be repeated later in the body of the poem, but just 
as the youth does not fully understand the implications of the messages he receives from the bird and the sea, the various meanings of these images are not yet fully apparent to the reader. Only upon completing the poem, and thus only in retrospect, can the reader assign significance to these descriptions. The introductory stanza concludes with an emphasis on the poet's status as "A man" (1.18) who is the "uniter of here and hereafter" (1.20).

After the mature poet's introduction, the body of the poem is divided into three sections which show the boy gradually awakening to become the "outsetting bard" (1.143). The first section opens with imagery of new life, imagery which contrasts with the images of life and death in the opening lines of the introduction. Rather than the "Ninthmonth," the boy notes that it is the "Fifth-month" with the "lilacscent" in the air and the "grass . . . growing" (1.24). The two birds arrive from Alabama, the "two together" with "their nest, and four light-green eggs" (1.27). The first-person narrator concludes: "every day I, a curious boy . . . / Cautiously peering, absorbing, translating" (11. 30-31). While the boy reveals that he not only peers and absorbs but that he also translates, the reader gets a clear sense that the boy's incipient poetic ability does not parallel that of the mature poet, as the mature poet takes "all hints" for his poetry but also swiftly leaps beyond those hints (1.21).

The first section closes with the first bird song, the song of "two together" (1.34), a song which, like the opening imagery of the section, emphasizes new life. Their song also, however, has suggestions of eternity, for the two birds are "minding no time, / While we two keep together" (11.39-40). What might be a hint of immortality quickly disappears as the next section opens with the death of the she-bird and the realization that they will not be together forever. At this point, the imagery changes and becomes highly charged. The "sound of the sea" echoes in the background (1.46) as the day changes to "night" and the sun to the "moon" (1.47). The narrator notes, using the past tense, that "I saw, I heard at intervals the remaining one, the he-bird" (1.50), thus suggesting a conflation of the mature poet and the boy, as the mature poet reflects back on his childhood experiences.

On the boundary between sea and land, "almost amid the slapping waves" (1.57), the bird sings of the loss of his mate; the narrator notes that "He pour'd forth the meanings which I of all men know" (1.60), suddenly changing from a conflation of the boy and the man to the voice of the mature poet alone as he states, in present tense, that his knowledge is beyond that of the boy, who, at this point, has only learned of lost love. Slowly, however, the voice of the mature poet once again merges with the voice of the boy. The next stanza begins with the mature poet alone as he consoles the bird: "Yes my brother I know, / 
The rest might not, but I have treasur'd every note" (11.61-62), but concludes with the boy and mature poet conflation: "I, with bare feet, a child, the wind wafting my hair, / Listen'd long and long" (11.67-68). As a child, the poet is capable of listening and absorbing and translating the song of fulfilled love; the further song of loss of love, and by extension death and immortality, requires the capability of a more mature poet.

The second section, like the first, concludes with the bird's song as the mature poet translates the message of loss of love that the boy hears into an intricate, alternating pattern of sea or land imagery and night or moon imagery. ${ }^{9}$ At the end of his song, the bird attempts to stop the sound of the sea in order to hear the sound of his mate: "And do you wait a moment you husky-nois'd sea, / For somewhere I believe I heard my mate responding to me . . ." (11. 107-108). But the night reigns while the moon droops into the sea; the bird feels that his singing is useless because his song has become a song only about the loss of his mate (11.119-124). He has not been able to stop the sound of the sea, and his "happy life" is no more- "We two together no more" (11.125-129).

The third and concluding section of the poem emphasizes the boy's insight into mortality. Here, the voice of the first-person narrator, as a mature poet, as a boy, or as a conflation of the two, altogether disappears. The boy, now ecstatic, is described in the third-person as the love in his heart is first loosed (the lesson of fulfilled love) before the meaning of the second song sinks into his soul and "strange tears" course down his cheeks (the lesson of lost love) and, finally, the boy hears the sea "incessantly crying" as it hisses "some drown'd secret" "To the outsetting bard" (11.130-143). The boy becomes the boy-poet when he learns about love and unsatisfied love. Significantly, the "word out of the sea" still remains a secret.

The poem then turns from a third-person description of the boy to a dramatic presentation of his maturing process. The boy-poet first questions whether the bird was singing to his mate or if the bird was singing to him (1.145). He continues:

For I, that was a child, my tongue's use sleeping, now I have heard you,

Now in a moment I know what I am for, I awake,

And already a thousand singers, a thousand songs, clearer, louder and more sorrowful than yours,

A thousand warbling echoes have started to life within me, never to die. (11. 146-149)

The boy-poet's first impulse is to sing of what he has learned, and as he has perceived that the bird's song is about unsatisfied love, he notes that he will sing a tune more sorrowful than even the bird's. He exclaims: "Never more the cries of unsatisfied love be absent from me" as he has had a "sweet hell" aroused within his soul (11.153-156). The boy-poet 
feels his destiny, then, is to sing this "sweet hell" - to sing about the sweetness of fulfilled love ("we two together") and the hell of loss of love ("we two together no more").

Having learned, at this point, only about love and loss of love, the boy-poet asks for more, the "clew," "The word final, superior to all," from the sea (11.158-161). The sea unhurriedly responds with the refrain "death, death, death, death" (1.169), which is "neither like the bird nor like my arous'd child's heart" and which laves him "softly all over" (11.170-172). Nowhere in this description of the boy-poet's encounter with the sea and its message do we get an indication that he comprehends anything beyond the word "death." Rather, the boy merely (as if this were not enough for a youth) learns about the bird's mortality.

The concluding stanza returns to the distinct voice of the mature poet as he reflects on the importance of his experience. He once again notes the three songs heard by the boy, the three songs which, as a mature poet, he is able to fuse: the song of the two birds together (of fulfilled love), the song of the he-bird and his "own songs awaked from that hour" (of unfulfilled love), and the song of the sea, "the key, the word up from the waves" (of death and mortality) (11.174-180). The mature poet, in this fusion and in his recreation of this scene, goes beyond the insights of the boy and unites these insights with the opening images of life and death and life in death by reiterating, but only reiterating in a parenthetical statement (thus demonstrating his distance from the scene), the image of the endlessly rocking cradle. $\mathrm{He}$ states that with the songs of fulfilled and unfulfilled love, he will fuse

... the key, the word up from the waves,

The word of the sweetest song and all songs,

That strong and delicious word which, creeping to my feet,

(Or like some old crone rocking the cradle, swathed in sweet garments, bending aside, )

The sea whisper'd me. (11. 179-183)

Whitman deftly ends with one of the keys to the text as he once again conflates the boy-poet, who stands on the shore learning of mortality, and the mature poet, who sees beyond this mortality.

In discussing the songs of "the adult poet, the boy, and the bird," Janet S. Zehr concludes that "Whitman suggests that the second speaker, the boy, can understand or translate a simple song of love and naive happiness," and goes on to note that

The "death's carol," however, requires the mature mind of the poet to translate it. "Translating" becomes "now translating" before the long song occurs in the poem, suggesting that only now does the poet understand what he heard as a boy. ${ }^{10}$ 
A clear distinction exists between the boy who becomes the boy-poet through the unfolding drama of the poem and the mature poet who reflects back on, and indeed makes meaning out of, this drama some years later.

The poet's growth stops at the end of "Out of the Cradle" as he becomes the "outsetting bard," the artist initiate. Still ignorant of the final secret of the sea, of its fullest symbolic signification, the boy-poet has learned only of mortality through his experiences with the bird's fulfilled and unfulfilled love at the end of the first poem in the Sea-Drift cluster. With this in mind, a reconsideration of the second poem, "As I Ebb'd with the Ocean of Life," is due. Having learned of the mortality of the bird, the boy-poet feels that he must sing songs of life, songs that celebrate the period before death. Thus, the ocean in the second poem of the cluster, which was the sea that spoke the word "death" in "Out of the Cradle," becomes the ocean of life.

The first section of "As I Ebb'd with the Ocean of Life" begins with the poet reflecting on his one-time pride in his songs, as he was once "held by this electric self out of the pride of which I utter poems" (1.7), a pride which quickly disappeared when he "Was seiz'd by the spirit that trails in the lines underfoot" (1.8). The poet turns to the sea-drift at his feet before concluding:

These you presented to me you fish-shaped island,

As I wended the shores I know,

As I walk'd with that electric self seeking types. (11. 15-17)

As in "Out of the Cradle," two distinct voices appear-that of the artist initiate, no longer the boy-poet of "Out of the Cradle" but not yet the mature poet, who was at one time seized with despair; and that of the mature poet who now knows the shore and reflects back on his past experience of despair (the days when he wended the shores).

The second stanza then shifts to the voice of the artist initiate alone as he speaks in present tense:

As I wend to the shores I know not ... .

I too but signify at the utmost a little wash'd up drift . . . (11. 18-22)

The speaker here contrasts his knowledge with that of the speaker of the first section by admitting that he does not yet know the shores (note the shift in tense from "wended" to "wend"). He continues to develop his despair by chastising himself for his arrogrance and then concludes with a new insight:

I perceive I have not really understood any thing, not a single object, and that no man ever can,

Nature here in sight of the sea taking advantage of me to dart upon me and sting me, 
Because the artist initiate, now a man but not yet the "uniter of here and hereafter," has not yet learned the full significance of the "word out of the sea," he feels that the sea chastises him.

The third section parallels the conclusion of "Out of the Cradle" where the boy-poet asked for the "clew" from the sea. Here, however, the young man turns to his "father," the "fish-shaped island" (11.3940 ), and clings to him "so firm till you answer me something" (1.47). The section concludes with the artist initiate asking the father to breathe to him, as if to resuscitate him, for it is "the secret of the murmuring I envy" (1.50). The young man understands that he has not fully heard the sea's message, for it is still only a secret that is murmured, and thus that the basis of his poetry at the end of "Out of the Cradle," the bird's mortality, is not fully sufficient.

The fourth section presents the poet on the verge of another awakening. He tells the sea to continue rustling at his feet "as I touch you or gather from you" (1.54). The stanza continues with imagery of both gathering and of death, the "little corpses" that make up the sea-drift, and concludes with the poet becoming a piece of sea-drift:

We, capricious, brought hither we know not whence, spread out before you, You up there walking or sitting,

Whoever you are, we too lie in drifts at your feet. (11. 69-71)

The poet has become one of his own poems about death which lie scattered at the confluence of the land and the sea, life and death, the present and the future. Although he still has not reconciled these dualities, and therefore is not yet the "uniter of here and hereafter," he has at the end of "As I Ebb'd" learned of his own mortality and thus gone beyond the message of "Out of the Cradle." He indicates this lesson in another parenthetical statement:

(See, from my dead lips the ooze exuding at last,

See, the prismatic colors glistening and rolling). . . . (11. 59-60)

The poet can no longer sing of his knowledge of the bird's mortality, for he has suddenly gained an insight into his own mortality.

R. W. French, in his detailed analysis of "As I Ebb'd," comes to a similar conclusion. According to French, in "As I Ebb'd,"

death is not to be praised or celebrated . . . it is simply not available as consolation in any form. Death in "As I Ebb'd" offers no special insights, no entrance into eternity, no enduring calm; it is a way of nature, no more: all life dies, and that is a fact. ${ }^{11}$

With his extended knowledge of mortality, of the mortality of all things, 
the poet does not feel that he can return to the creation of poetry. $\mathrm{He}$ has gained a further insight into life and death, an insight which has destroyed the former basis of his creativity.

The next poem in the cluster, "Tears," shows the poet thrown into despair because of his new found knowledge. The poet, on the beach alone at night, sheds "Moist tears" (1.5) as he hears "the unloosen'd ocean, / Of tears! tears! tears!" (11.12-13). Significantly, this short poem recalls the he-bird in "Out of the Cradle" immediately after he has lost his mate: "Down almost amid the slapping waves, / Sat the lone singer wonderful causing tears" (11.57-58). The difference in these scenes is that, while in "Out of the Cradle" the "stars glisten'd" as the bird shed his tears (1.55), in "Tears" there is "not a star shining, all dark and desolate" (1.4).

Although "Tears" seems to show a regression in the progress of the poet, he has actually moved forward in realizing that songs of mortality are not satisfactory. The bird, as the boy's spiritual guide, continues to teach the artist initiate in the next poem, "To the Man-of-War-Bird."12 In this poem, the bird sleeps "all night upon the storm," finally bursting through the storm and ascending above it (11.1-3). The young poet, after accepting his own mortality in "As I Ebb'd," returns to the guidance of the bird depicted in "Out of the Cradle" in order to find a way to move beyond the lesson of universal mortality and thus beyond his despair in "Tears."

In "To the Man-of-War-Bird," Whitman begins a shift in his symbolism from that of the bird, who teaches the young boy of death and then prepares him for further insights, to that of the ship, which dominates the remainder of the poems in the cluster. In the fourth poem of the cluster, the narrator is "on deck" watching the bird (1.6), who is later called a "ship of air" (1.16). The ship imagery becomes important because it allows the poet a new type of relation with the sea of immortality. ${ }^{13}$ Instead of floundering as a piece of sea-drift, the poet finds a suitable metaphor that will allow him to transcend the lesson of death and mortality and cross the sea of time. As Walter Sutton notes in his discussion of "Crossing Brooklyn Ferry," the visual images that Whitman uses to represent "the experience of the voyaging poet are all subordinated to the image of the ship, or ferryboat, which crosses the river (of time) from gate to gate (birth and death) and which supplies the poet his perspective as he recognizes the 'universality' of his particular experience" aboard the ship. ${ }^{14}$ The ship becomes, then, not only a metaphor for the soul crossing to immortality but also a metaphor for poetic expression. ${ }^{15}$

The next poem emphasizes the change to ship imagery and hints further at its significance. In "Aboard at a Ship's Helm," the "young steersman" (1.2) safely and gaily leads the ship on its way (1.9). The 
concluding lines delineate the significance of the ship in the poem:

But O the ship, the immortal ship! O ship aboard the ship!

Ship of the body, ship of the soul, voyaging, voyaging, voyaging. (11. 10-11)

After establishing the importance of the ship image, Whitman turns to a description of a young child. "On the Beach at Night" depicts, like "Out of the Cradle," a child on the beach during autumn. ${ }^{16}$ As the clouds cover the stars in the night sky, like they did in "Tears," the child begins to weep (11.4-13). Here, however, unlike the silent father in "As I Ebb'd," the child's father, who stands at her side, gives her the answer, the further "clew." He tells her that "The ravening clouds shall not long be victorious, / They shall not long possess the sky" (11.1718), for

They are immortal, all those stars both silvery and golden shall shine out again, The great stars and the little ones shall shine out again, they endure,

The vast immortal suns and the long-enduring pensive moons shall again shine.

(11. 20-22)

The father, much like the narrator in Hopkins's "Spring and Fall," asks the child whether it is for the stars alone that she cries. As the artist initiate learns about mortality in "As I Ebb'd," the child here learns, from the disappearance of the stars, about her own death. But her insight goes beyond this when she also receives a hint of immortality. In another parenthetical statement, Whitman has the father admit that "I give thee the first suggestion, the problem and indirection" (1.27).

Just as the young poet is poised for one final awakening at the end of "To the Man-of-War-Bird," so, too, is the girl ready to hear the message of immortality. The next poem does not, however, fully elaborate such a message; instead, "The World below the Brine" reemphasizes the moment before the final awakening. The poem begins with a list of plants and animals that exist below the surface of the sea, along with a description of their various activities, before moving to a description of the world above the surface of the water, "to the subtle air breathed by beings like us who walk this sphere" (1.10). The poem concludes with a further remove; after describing the world below the brine and the world above the brine, Whitman hints of a further world: "The change onward from ours to that of beings who walk other spheres" (1.11).

The various spheres either hinted at or delineated in "The World below the Brine" ultimately become united by an immortality that interlocks all spheres, an immortality which is finally described in "On the Beach at Night Alone." In this next poem, the poet stands "On the beach at night alone," listening to the "husky song" of the sea and 
watching "the bright stars shining" when he thinks "a thought of the clef of the universes and of the future" (11.1-3). The poet continues:

A vast similitude interlocks all,

All spheres, grown, ungrown, small, large, suns, moons, planets,

All distances of place however wide,

All distances of time ... .

All lives and deaths, all of the past, present, future,

This vast similitude spans them, and always has spann'd,

And shall forever span them and compactly hold and enclose them. (11.4-14)

The final "clew," the true "key" up from the sea, has been realized in that the poet now reveals that all is interlocked, all space and all time, in a "vast similitude" of immortality.

Robin Fast claims that the Sea-Drift cluster ends not by "emphasizing transcendence and immortality" but rather with an indication of "the value [Whitman] continued to place on the known world."17 And yet the last three poems of the cluster-"Song for All Seas, All Ships," "Patroling Barnegat," and "After the Sea-Ship"-most thoroughly delineate the importance of the ship imagery which is at the heart of Whitman's message of immortality. In the first of these poems, Whitman begins by telling the sea to flaunt its flags before concluding:

But do you reserve especially for yourself and for the soul of man one flag above all the rest,

A spiritual woven signal for all nations, emblem of man elate above death,

. .

A pennant universal, subtly waving all time, o'er all brave sailors,

All seas, all ships. (11. 17-23)

After once again demonstrating the symbolic nature of the ship sailing on the sea, of its reference to immortality, Whitman describes, in "Patroling Barnegat," "A group of dim, weird forms, struggling, the night confronting" (1.13). ${ }^{18}$ Symbolically, these dim forms represent both Whitman's individual poems heralding the message of immortality and souls, sailing on the sea, confronting death and what exists beyond. Just as the artist initiate became a corpse, a piece of sea drift, and thus symbolically one of his own poems, in "As I Ebb'd," here, too, the immortal soul becomes a poem. ${ }^{19}$

The last poem of the cluster, "After the Sea-Ship," demonstrates the poet's maturity in that he has fully realized the sea's message. Here, the poet returns once again, as in the opening of the body of "Out of the Cradle," to imagery of life. He describes the "undulating waves" (1.6), the "yearnfully flowing" waves (1.9), which follow in "The wake of the sea-ship after she passes, flashing and frolicsome under the sun" (1.10). The conclusion of the cluster, like the conclusion of the first poem of the 
cluster, returns to the image of the opening of Sea-Drift, where the cradle was endlessly rocked by the sea's waves, thus bringing the theme of immortality full circle. "Out of the Cradle," a poem which demonstrates the boy-poet's growing awareness of mortality, provides the foundation for a later realization of the concept of immortality, a concept which can now be embodied in the ship passing by in "After the Sea-Ship."

Because most critics have concentrated only on the opening poem of the Sea-Drift cluster and have attempted to see in that poem the full growth of the poet, the richness of the cluster as a whole has been lost. While "Out of the Cradle Endlessly Rocking" taken alone certainly reveals both the mature poet's intimations of immortality as well as the boy-poet's awakening, an analysis of the cluster as a unified series of poems closes the gap between the outsetting bard and the mature poet. The artist initiate's gradual comprehension of first a particular mortality and then of the mortality of all things sets the stage for the mature poet's deeper intimations of immortality, intimations which are then embodied in the ship imagery of the later poems of the cluster. ${ }^{20}$

\section{University of Tennessee}

\section{NOTES}

1 Robin Riley Fast, "Structure and Meaning in Whitman's Sea-Drift," American Transcendental Quarterly 53 (Winter 1982), 49-66; and Robert LaRue, "Whitman's Sea: Large Enough for Moby Dick," Walt Whitman Review 12 (Sept. 1966), 51-59.

While both of these articles analyze the entirety of the Sea-Drift cluster, their focus is rather different from mine. Robin Fast concentrates on how the cluster shows the poet's testing and confirmation of his poetic vocation. He claims that "Out of the Cradle" shows the entire process of the poet's growth, from boy-poet to mature poet, and then analyzes the other ten poems as a test of the insights achieved in this first poem: the first two poems showing despair, the next six showing "resolution and recovery," and the last two poems demonstrating "recovered assurance" (50). Robert LaRue concentrates on the "sea-symbol," noting that it is abstractly equated with "eternity." According to LaRue, because the sea "has so many aspects" it is used to signify many different modes and forms of the eternal (58).

2 Leo Spitzer, "Explication de Texte Applied to Walt Whitman's Poem 'Out of the Cradle Endlessly Rocking,"” ELH: A fournal of English Literary History 16 (1949), 245.

3 Gay Wilson Allen, A Reader's Guide to Walt Whitman (New York: Farrar, Straus, and Giroux, 1970), 194. Allen echoes these sentiments in his critical biography, The Solitary Singer (New York: New York University Press, 1967), 235-236.

4 Fast, 52.

5 Other critics who suggest a conflation of the outsetting bard and the mature poet include Edwin Haviland Miller, Walt Whitman's Poetry: A Psychological fourney (New York: New York University Press, 1968), 181-184; James E. Miller, Jr., A Critical Guide to Leaves of Grass (Chicago: University of Chicago Press, 1957), 106-107; Tracey 
R. Miller, "The Boy, the Bird and the Sea: An Archetypal Reading of 'Out of the Cradle," Walt Whitman Review 19 (Sept. 1973), 102; Char Mollison and Charles C. Walcutt, "The Emersonian Key to Whitman's 'Out of the Cradle Endlessly Rocking,", Arizona Quarterly 37 (Spring 1981), 16; David M. Stuehler, "Significant Form in Whitman's 'Out of the Cradle Endlessly Rocking,"' Calamus: Walt Whitman Quarterly: International 10 (April 1975), 29; Mary Ann Turner, "Reconciliation of Love and Death in 'Out of the Cradle' and Other Poems," Walt Whitman Review 18 (Dec. 1972), 124; Michael Van de Berg, "'Taking All Hints To Use Them': The Sources of 'Out of the Cradle Endlessly Rocking," W Walt Whitman Quarterly Review 2 (Spring 1985), 15; Harry R. Warfel, " 'Out of the Cradle Endlessly Rocking," "Tennessee Studies in Literature 3 (1958), 86; Stephen E. Whicher, "Whitman's Awakening to Death-Towards a Biographical Reading of 'Out of the Cradle Endlessly Rocking,'" in Edwin Haviland Miller, ed., A Century of Whitman Criticism (Bloomington: Indiana University Press, 1969), 287.

6 James Perrin Warren, “The 'Paths to the House': Cluster Arrangements in Leaves of Grass, 1860-1881," ESQ: A Fournal of the American Renaissance 30 (1984), 67.

7 As Allen notes in The Solitary Singer, the first stanza was separated from the body of the poem and entitled "Pre-Verse" in its original published form (233).

8 Walt Whitman, Leaves of Grass, Sculley Bradley and Harold W. Blodgett, eds. (New York: Norton, 1973), 11. 20-22. Further references to this text will be noted parenthetically by line numbers. I will concentrate my discussion on the final form of the Sea-Drift cluster in the 1881 edition as I believe that it is only in its final form that the cluster fully embodies the theme of immortality with all of its symbolism. For a good discussion of the evolution of the cluster and all of Leaves of Grass, see Thomas Edward Crawley, The Structure of Leaves of Grass (Austin: University of Texas Press, 1970), 165-226.

9 For an excellent discussion of the symbolic imagery in "Out of the Cradle," see James E. Miller, Jr., A Critical Guide to Leaves of Grass, 107-110.

10 Janet S. Zehr, "The Act of Remembering in 'Out of the Cradle Endlessly Rocking," Walt Whitman Quarterly Review 1 (Sept. 1983), 24.

Janet Zehr astutely discusses the many conflations of time in "Out of the Cradle"; instead of separating the voices in the poem as I have attempted, Zehr shows how Whitman broke down the barriers of time, thus bringing the voices together.

11 R. W. French, "From Major to Minor: A Reading of 'As I Ebb'd with the Ocean of Life,"” Walt Whitman Quarterly Review 7 (Fall 1989), 73.

12 In The Ecstatic Whitman: Literary Shamanism and the Crisis of the Union (Columbus: Ohio State University Press, 1986), George B. Hutchinson notes that the role of the bird in "Out of the Cradle" "has universal correspondences, birds having archaic connections with religious awakening and with the concept of the soul. They frequently serve as spiritual guides in initiatory experiences . . ." (128). See also Leo Spitzer, "Explication de Texte," 239.

13 For an excellent discussion of the symbolic value of the sea, and especially its relation to immortality, see Robert LaRue, "Whitman's Sea," 51-59.

Significantly, "To the Man-of-War-Bird" was not added to the cluster until 1881. While Whitman had already incorporated the ship imagery by 1876 , the importance of the shift from bird to ship imagery was not fully developed until the final version of the cluster. 
14 Walter Sutton, "Whitman's Poetic Ensembles," in Roy Harvey Pearce, ed., Whitman: A Collection of Critical Essays (Englewood Cliffs: Prentice-Hall, 1962), 123.

15 For an excellent discussion of the importance of ship imagery as a symbolic representation of both poetry and immortality, see George B. Hutchinson, "'The Laughing Philosopher': Whitman's Comic Repose," Walt Whitman Quarterly Review 6 (Spring 1989), 176.

16 I find it significant that, at the moment that Whitman shifts from bird imagery to ship imagery, from searching for the meaning of death to realizing the possibility of immortality, he also ends his descriptions of the progress of the outsetting bard. Instead, the child in "On the Beach at Night" is a young girl, and the remainder of the poems in the cluster turn to abstractly or symbolically (through ship imagery) discussing the theme of immortality.

For a discussion of the apparent discrepancy in this shift, from a natural symbol and a direct relation between poet and reader to an artificial symbol and a symbolic relation, see Gregory M. Haynes, "Running Aground in Barnegat Bay: Whitman's Symbols and Their Rhetorical Intentionalities," in Joann P. Krieg, ed., Walt Whitman: Here and Now (Westport: Greenwood Press, 1985), 115-116.

17 Fast, "Structure and Meaning," 62.

18 Two detailed readings have been done on this poem, each with different conclusions. Gregory M. Haynes notes the ambiguous use of symbolism in the poem, concluding that "Patroling Barnegat" is "perhaps Whitman's greatest achievement as an artificer of symbol" "'Running Aground in Barnegat Bay," 116). R. W. French, on the other hand, reads the poem only on a naturalistic level; he calls the poem "an unusually dark poem. There is nothing in it capable of redeeming the time, nothing of joy or love or human magnificence, nothing of hope or consolation" ("Whitman's Dark Sea: A Note on 'Patroling Barnegat,"” Walt Whitman Quarterly Review 1 [Dec. 1983], 52).

While clearly the poem is quite dark, the hope or consolation that French wants to see in Whitman's poem is indeed missed when isolated and read literally; however, as I hope that I have demonstrated, when read within their context, all of the poems of the Sea-Drift cluster take on a deeper signification. While immortality does pose hope for the human soul, when the human body confronts the end of life, the scene necessarily becomes dark and grim.

19 As many poets before Whitman have known, writing poetry extends poets beyond their own time and connects them to the future; thus, the poet achieves a kind of literary immortality. This knowledge is clearly at the heart of the discussion of death in "As I Ebb'd," for the poet's despair arises not only from a knowledge of his own death but also from an intuition that no one may read his poetry - a kind of literary death. It also explains why Whitman turns from discussing the poet's progress towards knowledge of immortality to poems which embody it symbolically. In addition, the significance of the title of the cluster, Sea-Drift, as well as the shift to ship imagery, becomes apparent after comparing "As I Ebb'd" and "Patroling Barnegat."

20 While an analysis of the place of the Sea-Drift cluster within the larger framework of Leaves of Grass is clearly beyond the scope of my discussion, it is interesting to note in conclusion that several critics have pointed to this cluster as a turning point in the collection as a whole. Thomas Edward Crawley, in The Structure of Leaves of Grass, notes that "This group of poems ... effects an important shift in emphasis-from exploration to introspection, from materialism to spiritualism, from individuality to all-inclusive spirituality" (140). Significantly, the inclusion of the ship imagery in the 
cluster emphasizes the shift in the collection; as is well known, the ship became one of Whitman's predominant symbols in his later poetry as he eventually became absorbed with more spiritual matters. 